OCDO MONTHLY PROJECT STATUS REPORT

LAND APPLICATION USES OF DRY FGD BX-PRODUCTS

OCDO GRANT AGREEMENT NO. CDO/D-89-35

STATUS REPORT NUMBER 30

REPORTING PERIOD - JULY 1993

\title{
DISCLAIMER
}

This report was prepared as an account of work sponsored by an agency of the United States Government. Neither the United States Government nor any agency thereof, nor any of their employees, makes any warranty, express or implied, or assumes any legal liability or responsibility for the accuracy, completeness, or usefulness of any information, apparatus, product, or process disclosed, or represents that its use would not infringe privately owned rights. Reference herein to any specific commercial product, process, or service by trade name, trademark, manufacturer, or otherwise does not necessarily constitute or imply its endorsement, recommendation, or favoring by the United States Government or any agency thereof. The views and opinions of authors expressed herein do not necessarily state or reflect those of the United States Government or any agency thereof. 


\author{
Land Application Uses of Dry FGD By-Products \\ Monthly Report \\ July, 1993
}

Warren A. Dick and Joel H. Beeghly

\title{
1.0 OSO Land Application Project
}

\subsection{Project Organization \& Plans}

A final draft budget revision for Phase 2 was given to OCDo for review. Because of the 7 month extension of Phase 2 to June 30 there is a projected shortfall of $\$ 27,575$ out of a budget of $\$ 1,737,075$ (or 1.68). This shortfall will grow slightly as the books for phase 2 are closed out. About half will be made up from unspent Phase 1 money and the balance reduced from the Phase 3 budget. The revisions to the statement of Work for Phase 2 and 3 were worked out but not completed pending discussion of Phase 3 site plans with Holmes Limestone in early August. Jackie Bird has expressed deep concern that the statement of Work is out of date particularly because of the new direction given to the research team to build a stabilized base for the cattle feedlot project out of the fixated Conesville wet FGD scrubber solids. The change inground water studies from an active mine site to an abandoned nine site must also be made. In doing field research on neutralizing and stabilization of acidic coal refuse from their Strasburg wash plant, Holmes Iimestone is interested very much in cooperating with us without requiring indemnification from ohio State University, Dravo Lime, other sponsors, and the FGD ash source or generator. Holmes is also interested in applications for road base stabilization in their stone Creek plant where coal is received from the mines, crushed, screened and shipped out (no washing). More discussion on plans for Holmes Limestone and the EORDC cattle feedlot demonstration sites is below.

\subsection{Technical Progress and Presentations}

2.1 A presentation on ash by-products from the Tidd PFBC project that was given orally by J. H. Beeghly at a DOE-METC conference in late June was written for the conference proceedings. A copy is enclosed. W. A. Dick and J. Harness assisted in editing this report.

2.2 Spreadability in a commercial size drop spreader and spinner spreader was demonstrated in a field of alfalfa using Ohio Edison - B\&W SNRB ash at the Wooster OARDC. A report will be written. A video and photos were taken.

2.3 Three papers were submitted about FGD research and land application to the International Land Reclamation and Mine Drainage Conference by Dravo Lime (J. H. Beeghly and J. College), W. A. Dick of Ohio state, and U.S. Dept. of Agriculture to be held in Pittsburgh, PA, April, 1994. 
July Monthly Report

Page -2-

2.4 Bob Carter of Dravo Lime Co., has greatly assisted the future capability to deliver dry FGD ash from the OsU spray dryer unit. He coordinated a plan with Bulk Transit and Jon Harris of McCracken Power station on how to load bulk pneumatic tankers by installing a special fitting in the silo. The truck cannot get under the silo due to height restriction but now it can connect a flexible hose to the silo from the outside. The osu spray dryer is scheduled to operate in late fall or early winter after a long outage.

2.5 Both OSU Civil Engineering and Dravo Lime Co. have continued to produce interesting strength data on fixated wet FGD sludge showing notable strength gains over 2008 from 28 to 85 days curing. Testing has included Mitchell, zimmer, and Conesville plus trying Dravo's Maysville lime kiln dust (LKD) as an amendment in lieu of extra pulverized quicklime ( $\mathrm{CaO}$ ).

\subsection{Field Demonstration site}

\subsection{OSU Bull Test Station - Stabilized Base}

The construction of the cattle feed lot stabilized base was completed at the OSU Bull and Ram Test Station EORDC using a blend of bed ash and conditioned cyclone ash. A total of 37 loads were used represented by four products forms: 1) dry cyclone ash as a soil cement to stabilize sub-soil, 2) conditioned cyclone ash at OMC for stabilized base delivered directly "fresh" from the silo conditioner, 3) dry bed ash to put a non-skid wearing surface on the final grade, and 4) a blend of bed ash and conditioned cyclone ash containing a minimum amount of water and loaded out from the stockpile made at the landfill. Bob Petigene, the ash handling contractor at Tidd and Cardinal AEP plants was a great help in doing the blending of bed and cyclone ash and loading out this last phase in a short amount of time. Steve Tutokey of Dravo Lime performed standard Proctor test on samples of the new blend. At 9 days curing, a strength of 700 psi was found and at 28 days was 990 psi. Bill Wolfe cored the base immediately after compaction with a rented vibratory roller to obtain test cylinders. The men at the Bull station worked very hard and need to be commented for the job done. This research will attract much attention. This project is indebted to AEP who paid the freight and Bob McConnell and Jack Cline of Ohio State University, Dept. of Animal Science. 
July Monthly Report

Page -3-

\subsection{Abandoned Mine Site}

The Fleming AML bids for reclamation as per the OSU Research design were submitted by contractors. The revised sludge management plan was revised by OSU Agronomy and $\mathrm{N}-\mathrm{V}$ iro and re-submitted to Ohio EPA, who now must issue a public notice of the project plan and schedule a public hearing on the plan. ODNR Division of Reclamation plans to proceed with bid acceptance followed by site preparation while the Ohio EPA studies the plan acceptance and goes through public review. We have been told to expect public resistance at the hearing. Studies investigating the impact of FGD on groundwater quality will occur at the abandoned mine land site. With the soil, plant, surface water quality data, and the area to be treated makes this a much more comprehensive study then could have occurred at an active mine site.

3.3 Coal Refuse stabilization

Holmes Limestone Company has suggested two ways they can use dry FGD by-product in a beneficial manner at their coal mine business. They are 1) stabilized base course material in the coal load out yard and screening plant and 2) stabilization and neutralization of acidic coal refuse from the wash plant. OSU will finalize a statement of work and budget to conduct this phase 3 research.

\subsection{Contract Problems}

See 1.0

\subsection{Project Work Schedule}

5.1 Refine work plans for use of FGD by-product at the Holmes Limestone active mine site.

5.2 Complete revision of Phase 2 and Phase 3 workplans.

5.3 Continue efforts to gain Ohio EPA approved for work plan at the Fleming AML site.

5.4 Complete rainulator studies on the agronomic plots.

5.5 Both W. A. Dick and L. Forster are to make presentations at the 1993 EPRI/EPA $\mathrm{SO}_{2}$ Control symposium, Boston, Mass.

5.6 Finalize mix design and make plans for shipping about 900 tons Conesville FGD by-product to OSU Bull Test station to construct stabilized base. Also, make plans to ship extra pulverized lime and lime kiln dust for use as strength accelerators. The willingness for AEP to help ship the Conesville material is needed. 


\section{$5013,100: 54$}

OCDO MONTHLY PROJECT STATUS REPORT

LAND APPLICATION USES OF DRY FGD BY-PRODUCTS

OCDO GRANT AGREEMENT NO. CDO/D-89-35

STATUS REPORT NUMBER 31

REPORTING PERIOD - AUGUST 1993

Joel H. Beeghly (412) 777-0711

warren A. Dick (216) 263-3877 
OCDO Report

August, 1993

Warren A. Dick and Joel H. Beeghly

\subsection{Land Application Project}

\subsection{Project Funding organization}

1.1.1 The revised statement of work was submitted to OCDO along with the final phase 2 budget and proposed phase 3 budget. Phase 2 ended June 30 with the exception of writing the Final report. Despite a 7 month extension, Phase 2 was completed only about 18 over the budget.

1.1.2 The budget process for Phase 3 with the DOE-METC was also reviewed with DOE-METC for the period July, 1994, to July, 1995.

1.1.3 Ruth Smith is the new contracts representative from OSURF replacing Gun Seren. Gun was very helpful to the project in revising budgets and projecting expenses.

1.1.4 Meetings were held with USGS to discuss their Phase 3 budget. The USGS was asked to do the acid base accounting on the R\&F overburden core logs.

\subsection{Reports and Technical Papers}

1.2.1 OCDO and other sponsors have expressed satisfaction and praise to osu in che quality of the Phase 1 report. Additional copies are being made. Work on the Phase 2 report has begun.

1.2.2 Warren Dick and John Raush made presentations at the EPRI-EPA-DOE $\mathrm{SO}_{2}$ Control Symposium. Warren spoke of the Phase 1 characterization and Phase 2 greenhouse work. John spoke on the economics of land application versus landfilling.

1.2.3 A report on the environmental impact (i.e. leachate) of the LIMB stockpile was finished and put in the process for external review before submittal to Ohio EPA.

\subsection{Field Test Projects}

\subsubsection{Fleming AMC}

Plans for the Ohio EPA public hearing on september 22 and a preliminary meeting with local politicians were made for the Fleming AML site. The contractor was chosen by the Division of Reclamation and earth work and site contouring has begun. 
OSU has completed negotiations with Ohio EPA on the site plan. A fact sheet was written and is attached. A fugitive dust permit will be required. We have to get General Motorg to "release" 200 ton of $\mathrm{FBC}$ ash (for the watersheds receiving no $\mathrm{N}-\mathrm{viro}$ soil).

\subsubsection{Holmes Limestone Coal screening Plant}

Two $5,000 \mathrm{sq}$. ft. test areas are being planned using General Motors FBC conditioned ash for base stabilization at the Holmes limestone Co. coal load out yard. One test will add the ash to the "coarse" size coal refuse removed in the coal wash plant. An effort is being made to get GM to pay for the backhaul freight at $\$ 16 / \mathrm{T}$. They will still gain a savings over the landfill tipping fee.

\subsubsection{Wet FGD Stabilized Base Material at osu Bull Test Center}

Plans were presented to AEP Ash Management Department to produce and donate approximately 1400 ton of fixated Conesville FGD solide to the osu Bull Test Center in southeastern Ohio. They agreed to cooperate and also deliver the material with a prescribed level of solids. Extra fly ash and lime will be added to enhance strength. At least three mix designs will be evaluated. After our initial curing period extra lime using lime fines $(1 / 4$ inch $x$ 0) or lime kiln dust from Maysville will be mixed at the feed lot in separate plots using a rotatiller in lieu of a pug mill. Unconfined compressive strengths of about $300 \mathrm{psi}$ are sought.

J. Bi.rd of OCDO considers this test top priority because of the interest by the Ohio Department of Development.

s. Tutokey of Dravo Lime performed proctor tests using lime kiln test which was suggested by AEP due its success in the tests in Columbus at the I-670 soil stabilization test site. At 28 days an unconfined compressive strength of 280 psi was attained.

\subsubsection{ODOT Rt. 83 Highway Reconstruction}

Bill Wolfe has instituted, in cooperation with ohio Dept. of Transportation (ODOT), plans to use Tidd PFBC material to repair an earth slide that has damaged approximately $1000 \mathrm{ft}$ of Rt. 83 south of Cumberland, ohio. The FGD by-product will be used af fill to replace the soil. As much as 14,000 $\mathrm{cu}$. yds may be required this fall.

\subsection{Contract Problems}

None (This is a 1st!) 
August 1993

Page -3-

\subsection{Projected Work Schedule}

3.1 Complete plans for Ohio EPA compliance. Construct plots at the Fleming site-to be treated next spring. Get clearance from GM for FBC ash alone treatment plot.

3.2 Continue formulating plans for work at Holmes Limestone site. Submit a proposal to GM to release FBC ash for Holmes coal load out yard stabilized base.

3.3 Present paper at the Pittsburgh Coal Conference.

3.4 Complete harvest and enter data obtained during first year of studies at the agronomic plots.

3.5 Complete plans for use of FGD Tidd by-products for O.D.O.T. soil for stabilization and embankment.

3.6 Construct osU feedlot with Conesville stabilized wet FGD by-product. 


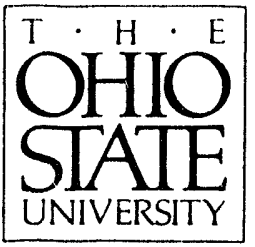

Ohio Agricultural Research

and Development Center

Department of Agronomy

1680 Madison Avenue

Wooster, OH 44691-4096

Phone 216-263-3878

FAX 216-263-3658

\section{Fact Sheet: AML Reclamation}

Project Title: Land Application Uses for Dry FGD By-Products Subproject Title: Use of FGD By-Product Materials as an Amendment for Reclamation of the Fleming AML Site

\section{What is the Project Objective?} Where will this Project
be Conducted?
What is the Composition of the FGD By-Products?

Will Other Materials Also be Used for Reclamation?
To demonstrate beneficial high-volume uses of clean coal technology by-products that are created when high sulfur coal is burned and the exhaust (flue) gases scrubbed. The abbreviation, FGD, which is short for Flue Gas Desulfurization, is often used to refer to these by-products. In the broadest sense, this project was created to encourage the use of Ohio coal. The people in Ohio who mine coal and whose livelihood depends on the use of Ohio coal are the ultimate beneficiaries of the results of this project.

The actively eroding and very acidic Fleming AML site located in Franklin Township, Tuscarawas County (west of Dover, $\mathrm{OH}$ ). This 40 acre site was mined and abandoned several decades prior to the Surface Mining and Reclamation Act of 1977.

Ohio State University has analyzed more than 50 FGD byproduct samples. They are made up of fly ash, limestone, and gypsum. Limestone and gypsum are commonly used to improve conditions for crop growth in acid agricultural soils.

Both topsoil and topsoil substitutes will also be used. Based on past research activities, a topsoil substitute composed of a mixture of limestone and organic matter provides the best reclamation results. Therefore we have proposed using a mixture of FGD by-product and sewage sludge. All materials will have been approved by Ohio EPA and the Ohio Department of Natural Resources prior to their use in the reclamation project. A management plan will also have been approved prior to application of any reclamation materials.

The FGD by-product and sewage sludge are from sources in Ohio.
Where are the Reclamation Materials Coming From? 


\section{What Will be the Rates Applied?}

\section{Who Will be Responsible for this Project?}

\section{What are the Expected Benefits?}

Approximately eight inches of topsoil will be applied to 26 acres of the Fleming site. Seven acres will receive a FGD/sewage sludge mixture applied at rates specified by Ohio Department of Natural Resources in accordance with Ohio EPA guidelines. An additional seven acres will be treated with topsoil, FGD, or FGD/sewage sludge mixture. Tests by the Ohio State University Soil Testing Laboratory indicate that approximately 40 tons/acre of limestone will be required. An additional 10 tons/acre will be added to the surface eight inches of the regraded spoil. FGD by-product with an equal amount of neutralizing power will require a total of 125 tons/acre be applied. The FGD/sewage sludge mixture will be applied at a rate of 250 tons/acre because the FGD comprises only $50 \%$ of this mixture. This high rate of the FGD/sewage sludge mixture will be applied to only four acres as part of an Ohio State University research study.

The reclamation of the Fleming AML site will be conducted in accordance with established procedures of the Ohio Department of Natural Resources. The plans for reclamation using the FGD/sewage sludge mixture are based upon two years of laboratory and greenhouse studies conducted at The Ohio State University.

Over $\$ 1$ million will be spent to monitor soil, plant, surface and groundwater quality at the site af ter reclamation has been completed. All measurements will be made under the supervision of personnel at The Ohio State University and the U.S. Geological Survey.

The most immediate benefit will be the restoration of a site that is causing environmental problems due to acid mine drainage and transport of toxic sediments to adjacent sites. Also, information gained from this demonstration project will provide long-term answers as to any potential benefits of using clean coal technology (FGD) by-products for reclamation of acidic materials.

For more information about the reclamation project at the Fleming AML site, call Warren Dick, Department of Agronomy, at 216-163-3877 or write to Warren Dick ai Department of Agronomy, The Ohio State University, 1680 Madison Avenue, Wooster, $\mathrm{OH} 44691$

Ohio State University has faculty and staff located at Columbus, Wooster and 13 outlying research locations. Support is provided by an appropriation from the Ohio Legislature, by federal funding, and by grants, gifts and contracts. 
$50,1 \ldots, 10: 54$

OCDO MONTHLY PROJECT STATUS REPORT

LAND APPLICATION USES OF DRY FGD BY-PRODUCTS

OCDO GRANT AGREEMENT NO. CDO/D-89-35

STATUS REPORT NUMBER 32

REPORTING PERIOD - SEPTEMBER 1993

Joel H. Beeghly (412) 777-0711

Warren A. Dick (216) 263-3877 


\section{OCDO MONTHIX REPORT}

September, 1993

\subsection{Land Application Proiect Results \\ 1.1 Project Organization \& Funding}

1.1.1 The final "official" revision of the Phase 2 statement of work and budget was submitted to OCDO after Dravo Lime approving same from OSU's submittal. Also, a more detailed Phase 3 statement of Work and budget was submitted to OCDO for the first time. Iargely due to the reduced USGS scope of work at the mine sites, the Phase 2 expenses will not significantly be more than the former budget in spite of 7 extra months work. A recap is attached.

1.1.2 A meeting was held with DOE-METC to discuss Phase 3 budget and their support. DOE will allocate funds for the fiscal year beginning october 1, 1994.

\subsection{Reports, Meetings, Conferences}

1.2.1 A workshop on the meaning and implications of the expansive mineral, ettringite, sponsored by DOE-METC and hosted by University of Kentucky was attended. Sam Traina, Randy Fowler, and Jerry Bigham of OSU Agronomy attended and gave a report. Bill Wolfe of osU Civil Engineering also gave a report. Joel Beeghly attended. All FGD by-products will generate ettringite but only some have shown swelling.

1.2.2 The Pittsburgh Coal Conference was attended by J. Beeghly and Rick Stehouwer who gave an oral presentation on some of the greenhouse results. A copy is enclosed of the published paper.

1.2.3 Two reports were submitted by osu Agronomy for review before external release. First, the report on LIMB pile environmental impact was likewise released by ohio Edison, B\&W, and Central Fuel Co. Second, a report on the SNRB ash spreadability field tests was reviewed and sent to Babcock \& Wilcox.

\subsubsection{General Motors CFBC, Pontiac, MI}

A meeting was held with Great Lakes N-Viro and General Motors, Pontiac, MI. Acting upon our lead, N-Viro has been using GM's CFBC ash to make their N-Viro soil which will be used at the Fleming $A M L$ site. In addition, we were meeting to set up delivery of CFBC ash alone for 2 of the 6 experimental watersheds. This quantity of 250 ton would have to be conditioned with water due to dust control requirements whereas N-Viro only gets dry silo material. GM was reluctant to release this 250 ton without first receiving approval of our Ohio EPA permit. GM reported they are using the FBC ash for stabilization of hazardous waste at one of their plants. 
September Monthly

Page -2-

We also discussed our interest in developing a field demonstration based on backhauling conditioned ash to the coai mine to construct a stabilized base in their (Holmes Iimestone stone Creek Yard) coal load out yard. Another application would be to mix dry or slightly moistened ash to coarse coal refuse to make stabilized base or fill material. The acid producing substances in the coal refuse would also be neutralized. Holmes Limestone suggested this experiment be delayed until next spring to avoid adverse fall weather and mud. Plans for treating fine coal refuse sludge have not progressed.

1.2.5 DOE-METC Meeting on Marketing Barriers.

Warren Dick attended the workshop on "Barriers to Increased Utilization of Coal Combustion/Desulfurization By-Products by Government and Commercial Sectors" sponsored by the Department of Energy's Morgantown Energy Technology Center on September 27 and 28. One result of this meeting is that the final report will now include a greater emphasize on land application uses of ashes and FGD by-products. The report of barriers is being prepared by the Energy \& Environmental Research Center, Grand Forks, North Dakota.

\subsection{Phase 3 Field Demonstration Projects}

\subsubsection{Fleming AML}

A public hearing was held by Ohio EPA September 22 to allow public comment on our proposal to study FGD use for AML reclamation with and without sewage sludge. Previously, a meeting on september 14 was arranged by Jackie Bird in the statehouse with state Representative, Greg DiDinato, Ohio DNR, Ohio EPA, Senator Burch's aid, and our group to discuss the issues. One key suggestion by Representative Greg DiDinato was to form a citizens advisory committee to oversee the Fleming Project. Prior to the september 22 hearing, many contacts were made to mount support for our project because many negative comments were expected. In fact, the Mayor of Dover, a local public health official, township trustees, and others spoke against it because of fear of endangering their ground water supply. The ohio EPA conducted the hearing and had 3 of the 6 panel members there to comment and answer questions. Other members were Professor $W$. Dick of osU, Mark Smith of the Ohio DNR AML Program, and Ralph Haefner of the USGS. We expect that Ohio EPA will still approve the project and will now require a fugative dust permit. Contractors of AML jobs have not herebefore been required this regulation. We expect the club 3000 group to intimidate the landowner and the contractor. 
September Monthly

Page -3-

J. Bird does not want the Project to get involved in any litigation or political crossfire. Ohio EPA should make a decision of their recommendation by November. Information is attached supplied by Great Lakes N-Viro that discusses their product and its role at the AML site along with other information. A newspaper clipping is also attached describing the public hearing.

\subsubsection{Stabilized Wet FGD Base Course Installed}

In a second OSU feedlot stabilized base experiment, (the first was using Tidd PFBC) fixated wet FGD scrubber by-product from Conesville AEP Plant was used where large round (1000 lb.) hay large round (1000 $\mathrm{lb}$.) hay bales are stored and eaten over the winter by brood cows. Fixated calcium sulfite/sulfate vacuum filter cake was mixed with fly ash 1.5:1.0 and pulverized quicklime (Maysville lime fines) in three mix designs. The amount of pulverized quicklime and timing of application was varied. The percent solids of the resultant mixes were specified to be a minimum of 60\%. The mixes were spread and compacted in two-6 inch lifts. The strength objective is to attain $500 \mathrm{psi}$ in 60 days.

About 1,500 tons was trucked by AEP to the OSU Research facility. Two truckloads of 1 ime fines were provided and delivered by Dravo Lime Co. For the most part all of the material got placed and compacted in an efficient manner. We were not able to test the use of lime kiln dust from Maysville. The feedlots are to be cored after periods of curing and tested for strength, permeability, and density. One lot using Conesville FGD is $216 \mathrm{x}$ $72 \mathrm{ft}$. Another is $150 \times 100 \mathrm{ft}$.

Bill Wolfe and Jack Cline worked on the mix designs. Jack Cline and Bob McConnell of OSU Animal science are owed a huge amount of gratitude for getting the test pads constructed in an efficient and safe manner. AEP Conesville personnel were likewise very cooperative and supportive. Steve Tutokey of Dravo Lime was of great assistance in constructing these test pads.

The three mixes were:

$\$ 1$ - About $42 \%$ solids filter cake got mixed with fly ash at a weight ratio of 1.5:1:0 fly ash: cake (dry weight). Five per cent lime fines was added at the feedlot via rotatiller in each 6" lift and compacted with a large drum roller. The normal addition of lime @ $1.5-1.78$ lime at Conesville was done. Thus, this Conesville $\mathrm{mix}$ is their normal mix assuming they have adequate amount of fly ash available and the filter cake solids is near 408. This mix material must cure about 4 days but not much more before being shipped. 
*2 - About 37\% solids filter cake got mixed with fly ash at a weight ratio of $1.5: 1.0$ and 58 pulverized lime at Conesville. At the osu feedlot, it was put down with $5 \%$ more lime fines mixed in.

*3 - Same as \#2 but no lime was added at the feedlot.

\subsubsection{ODOr Projects - Embankment and soil stabilization}

Bill Wolfe reports plans are set to use TIDD PFBC material on two different Ohio Department of Transportation (ODOT) projects. Ohio EPA and AEP are both cooperating.

\subsubsection{Agronomic Liming Plots}

Corn and alfalfa harvests have been completed for 1993. Approximately 500 water sample, collected as part of a rainulator study to evaluate surface water runoff quality from FGD treated soils, were combined according to hydrograph information and have been prepared for quality analyses.

\subsection{Contract Problems - See 1.3.1}

\subsection{Projected Work schedule}

3.1 Contact Ohio EPA about fugative dust permit for Fleming site.

3.2 Schedule steering Committee meeting in November.

3.3 Assist ODOT in use of TIDD by-product.

3.4 Joel H. Beeghly is to present paper at Coal Market Strategies Conference, st. Louis, Mo.

3.5 Warren A. Dick will assist in formation of local citizens advisory committee to oversee Fleming AML project.

3.6 Begin Phase 2 Final Report writing. 


\section{DRY FGD BY-PRODUCTS AS AMENDMENTS} FOR ACID MINE SPOIL

R.C. Stehouwer, P. Sutton, and W.A. Dick Department of Agronomy

Ohio Agricultural Research and Development Center Ohio State University Wooster, Ohio 44691

\section{ABSTRACT}

Reclamation of mine-sites with acid overburden requires the use of alkaline amendments and represents a potential high-volume use of alkaline dry flue gas desulfurization (FGD) by products. In a greenhouse study, 25-cm columns of acid mine spoil were amended with two FGD by-products; lime injection multistage bumers (LIMB) fly ash or pressurized fluidized bed (PFBC) fly ash at rates of $0,4,8,16$, and $32 \%$ by weight $(0,40,80,160$, and 320 tons/acre) Amended spoil was covered with $20 \mathrm{~cm}$ of acid topsoil amended with the corresponding FGD by-product to $\mathrm{pH} 7$. Column leachate $\mathrm{pH}$ increased with FGD amendment rate while leachate $\mathrm{Fe}, \mathrm{Mn}$, and $\mathrm{Zn}$ decreased. Leachate $\mathrm{Ca}, \mathrm{S}$, and $\mathrm{Mg}$ decreased with LIMB amendment rate and increased with PFBC amendment. Leachate concentrations of regulated metals were decreased or unaffected by FGD amendment except for Se which was increased by PFBC. Spoil $\mathrm{pH}$ was increased up to 8.9 by PFBC, and up to 9.2 by LIMB amendment. Spoil $\mathrm{pH}$ also increased with depth with FGD amendments of 16 and $32 \%$. Yield of fescue was increased by FGD amendment of 4 to $8 \%$. Plant tissue content of most elements was unaffected by FGD amendment rate, and no toxicity symptoms were observed. Plant $\mathrm{Ca}$ and $\mathrm{Mg}$ were increased by $\mathrm{LIMB}$ and PFBC respectively, while plant $\mathrm{S}, \mathrm{Mn}$ and $\mathrm{Sr}$ were decreased. Plant $\mathrm{Ca}$ and $\mathrm{B}$ was increased by $\mathrm{LIMB}$, and plant $\mathrm{Mg}$ and $\mathrm{S}$ by PFBC amendment. These results indicate dry FGD by-products are effective in ameliorating acid spoils and have a low potential for creating adverse environmental impacts.

\section{INTRODUCTION}

Dry FGD by-products are a mixture of conventional coal combustion ash (either bed or fiy ash), the $\mathrm{SO}_{2}$ reaction product (primarily anhydrite, $\mathrm{CaSO}_{4}$ ), and unspent sorbent (generally lime, limestone, or dolomite). Due to the unspent sorbent, dry FGD by-products have a significant neutralization potential $(1,2)$. These FGD by-products may also be high in solubio salts and contain some trace elements of environmental concern (2). Development of uses for these by-productswhic for these by-products which are demonstrated to be environmentally benign or even beneficta would significantly reduce the costs of $\mathrm{SO}_{2}$ emission control by eliminating the expense ce landfilling these materials.

One potential high-volume use for dry FGD by-products is in reclamation of surfaco $\infty$ mines with acid spoil materials. Such areas are frequently strongly acidic and drainage we can cause severe off-site environmental damage due to its acidity and high salt content (s)
The objective in surface mine reclamation is to prevent the occurrence of acid mine drainage revegetating and stabilizing spoll acidity and limiting further oxidation of iron disulfides by the effects of dry FGD by-products on greenhouse study was conducted to investigate environmental impacts, particularty with spoil acidity and plant growth, and possible environmental impacts, particularly with respect to the solubility and mobility of salts and
potentially toxic trace elements.

\section{MATERIALS AND METHODS}

Spoil and topsoil were collected from an active surface coal mine located in east-central Ohio and dry FGD by-products were collected from two different scrubber process: lime injection multistage bumer (LIMB), and pressurized fluidized bed combustion (PFBC) (Table 1). Spoil placed in $60 \mathrm{~cm}$ PVC columns (15 cm ts ates of $0,4,8,16$, and $32 \%$ by weight and $(0.4 \%)$ and PFBC $(0.8 \%)$ to bring its $\mathrm{PH}$ to 7 ,er). Topsoil $(5.4 \mathrm{~kg})$ was mixed with LIMB treated with the same FGD bring its $\mathrm{pH}$ to 7 , and placed in the PVC columns above with all treatments replicated $\&$ times and amanged factorial experimental design was used (complete blocks.

After filling the columns, sufficient deionized water was added to each column to produce between 150 and $200 \mathrm{ml}$ of leachate. Columns were then planted each column to produce 31 tall fescue (Festuca arundinacea Schreb.). After a 3-mo growth period fescue 30 seduck harvested once each month for a total of six harvests. Plant tissue growth period fescue was analyzed for $\mathrm{N}$ and for the elements listed below. Plant tissue was dried, weighed, and leached following the sixth elements listed below for leachate analysis. Columns were only to replace evapotranspiration losses. Following leachings the columns were watered were sampled at various depth interals. Following the final leachate collection, columns analyzed for crystalline minepth intervals for $\mathrm{pH}$ determination, and selected samples were electrical conductivity, for $A s, B$. $\mathrm{Ni}, \mathrm{P}, \mathrm{Pb}, \mathrm{S}, \mathrm{Sb}, \mathrm{Se}, \mathrm{Si}$ and $\mathrm{Zn} \mathrm{Ba}$ and for $\mathrm{Cl}$, $\mathrm{SO}_{3}{ }^{2-}$, and $\mathrm{SO}_{4}{ }^{2-}$ by ion chromatography

\section{RESULTS AND DISCUSSION}

Both FGD by-products were effective in raising spoil pH (Fig. 1). Because of its lime and portlandite content the LIMB by-product raised the $\mathrm{pH}$ of the first leachates to its lime and second leaching $\mathrm{pH}$ had decreased to below 10 . The $\mathrm{PFBC}$ frst leachates to 12 , but by the due primarily to $\mathrm{Ca}$ and $\mathrm{Mg}$ carbonates with 10 . The PFBC by-product, in which alkalinity is highest amendment rate. At application some periclase, initially raised $\mathrm{pH}$ to 9.5 at the neutralization potentials of about $60 \% \mathrm{CaCO}_{3}$ equivalency, increased $\mathrm{FGD}$ by-products, with sustained this $\mathrm{pH}$ throughout this 8-mo experiment it should bed spoil pH to around 7 and FGD by-products vary considerably in their total neutralization be noted, however, that dry amount of material needed to neutralize acidity in theutralization potential (2). Therefore the one type of FGD by-product to another acidity in the treated spoil is expected to vary from needed to neutralize increase the $\mathrm{pH}$ and base status of spoil zone may be desirable if downward leaching will spollow the treated zone.

Conditions of high $\mathrm{pH}$, high levels of soluble $\mathrm{Ca}$ and $\mathrm{SO}^{2-}$. ( $\left(\mathrm{Ca}_{6} \mathrm{Al}_{2}\left(\mathrm{SO} \mathrm{O}_{1}\right)_{2} \mathrm{OH}\right)$ cementitious secondary minerals. $\left(\left(\mathrm{Ca}_{6} \mathrm{Al}_{2}\left(\mathrm{SO}_{4}\right)_{3}(\mathrm{OH})_{12} \cdot 26 \mathrm{H}_{2} \mathrm{O}\right)\right.$ ) formation occurred throunerals. Extensive ettringite $32 \%$ LIMB. Ettringite is highly expansive and ced throughout the spoil amended with 16 and water movement and root extension amendment cementing aypsum. This very differum of the hydration of anhydrite to for mineral formation is due components.
con differing mineralogies and solubilities of their constituent 
The first leachates, collected from previously air-dry spoil materials, were not representative of equilibrium conditions in the spoil+amendment mixes. This discussion, therefore, will focus on the final leachates which, because they were collected after 8 months of reaction and equilibration, provide a much better indication of equilibrium soil solution chemistry.

Leachate soluble salt concentrations (as determined by EC) were decreased by LIMB and increased by PFBC amendment up to $16 \%$ (Table 2). Similar patterns were seen in amendment effects on concentrations of $\mathrm{Ca}, \mathrm{Mg}$ and $\mathrm{S}$, the major elements in the leachates. In all leachates, greater than $90 \%$ of the totaIS was in the form of $\mathrm{SO}^{2 .}$. Concentrations. In all $\mathrm{Ca}$ and $\mathrm{S}$ in $\mathrm{LIMB}$ amended solity of gypsum $\left(\mathrm{CaSO}_{4} \cdot 2 \mathrm{H}_{2} \mathrm{O}\right.$ ) where ettringite did not form. Because ettringite is much less soluble than gypsum, $\mathrm{Ca}$ and $\mathrm{S}$ concentrations decreased in leachates where ettringite was present even though the total amount of $\mathrm{Ca}$ and $\mathrm{S}$ in the columns increased. The increase in $\mathrm{S}$ at $32 \%$ LIMB was accompanied by an increase in $\mathrm{K}$ and $\mathrm{Na}$. With PFBC amendment, leachate $\mathrm{Ca}$ appeared to be controlled by the solubility of gypsum, while $\mathrm{Mg}$ and $\mathrm{S}$ were likely controlled by the solubility of epsomite ( $\mathrm{MgSO}, 6 \mathrm{H}_{2} \mathrm{O}$ ). Leachate $\mathrm{S}$ and $\mathrm{Mg}$ went to much higher levels with PFBC amendment than leachate $S$ and $\mathrm{Ca}$ with LIMB amendment because epsomite is with PFBC amendment than leachate $S$ and $\mathrm{Ca}$ with $\mathrm{LIMB}$ amendment because epsomite is $\mathrm{PFBC}$ was apparently the result of gypsum cementing. Thus the presence of $\mathrm{Mg}$ in the PFBC by-product gives it a greater potential for excessive salt loading than the LIMB by-product.

Leachate concentrations of $\mathrm{Al}, \mathrm{Fe}, \mathrm{Mn}$, and $\mathrm{Zn}$, which are often toxic in acid conditions, decreased with FGD amendment (Table 2). This was expected since the solubility of each of these elements is greatest under acid conditions and decreases rapidly with increasing pH (4). Table 2 gives leachate concentrations of elements which are of environmental concern
(4) and have been regulated with respect to land application of sewage sludge. Not listed are $\mathrm{Hg}$ and $\mathrm{Pb}$. Mercury was below detection limit $\left(<0.04 \mathrm{mg} \mathrm{kg}^{-1}\right)$ in all of the column leachates and was also not deterted $\left(<0.0002 \mathrm{mg} \mathrm{kg}^{-1}\right)$ in Toxicity Characteristic Leaching Procedure (5) extracts of LIMB or PFBC by-product. Lead was detected at a level of $0.12 \mathrm{mg} \mathrm{kg}^{-1}$ in leachates from unamended spoil In all other leachates, $\mathrm{Pb}$ was below detection limit $(0.04$ chate $\mathrm{Cd}, \mathrm{Cu}$, and $\mathrm{Ni}$ decreased with increasing FGD amendment (Table 2). These results are consistent with most studies of trace metal behavior in solls which have found that trace metal solubility and mobility decreases as $\mathrm{pH}$ increases above the acid range $(6,7)$. Thus with respect to these metals there appears to be little potential for environmental contamination as a result of using FGD by-products as spoil amendments.

With respect to some oxyanions of concern, As remained below $0.05 \mathrm{mg} \mathrm{kg}^{-1}$ and was not ( $B$ species are relatively water soluble (7) and in actual mine reclamation, leaching due to natural precipitation may rapidly move soluble $B$ below the root zone, thereby decreasing the potential for B phytotoxicity.

With PFBC amendment Se concentrations increased at all amendment rates except $32 \%$ the LIMB by-product (Table 1), it would appear $\mathrm{Se}$ in the spoils was present in part as adsorbed $\mathrm{SeO}_{4}{ }^{2-}$ or $\mathrm{SeO}_{3}{ }^{2 \cdot}$, these species could have been mobilized by exchange with $\mathrm{SO}_{4}{ }^{2-}$. Due to their weak acid character, $\mathrm{SeO}_{4}{ }^{2-}$ and $\mathrm{SeO}_{3}{ }^{2 \cdot}$ should be held more strongly by soils than $\mathrm{SO}_{4}{ }^{2-}(4)$, thus high $\mathrm{SO}_{4}{ }_{4}^{2-}$ concentrations would be necessary to exchange with $\mathrm{SeO}_{4}{ }_{4}^{2-}$ and $\mathrm{SeO}_{3}{ }^{2-}$. The decrease in $\mathrm{Se}$ with $32 \% \mathrm{PFBC}$, where there was also a sharp decreease in $\mathrm{SO}_{4}{ }^{2-}$, is consistent with such a mechanism

Fescue growth was increased by FGD amendment of 4 to $8 \%$, and decreased at higher rates, although good growth was achieved at all amendment rates (Fig. 2). It should be emphasized that the $20 \mathrm{~cm}$ of topsoil in all columns was amended with LIMB or PFBC to achieve a pH of
7. Therefore the underlying spoil with much higher FGD amendments had little effect on plant growth in these experiments. Root growth into the spoil was prevented by LIMB amendments of 16 and $32 \%$ and PFBC amendment of $32 \%$. This could have been caused by a number f fours been caused by number of factors including cementing, high $\mathrm{pH}$, and high soluble salts. Fescue tissue composition was relatively unaffected by the FGD amendments and no symptoms of phytotoxicty were observed. LIMB amendment decreased tissue $\mathrm{S}, \mathrm{Mn}$, and $\mathrm{Zn}$, and increased tissue $\mathrm{Ca}$ and B. PFBC amendment decreased tissue $\mathrm{Mn}$ and increased tissue $\mathrm{Mg}$.

\section{CONCLUSIONS}

Both dry FGD by-products were effective in neutralizing spoil acidity and decreasing the solubility of elements which are often phytotoxic under acid conditions. At amendment rates of $16 \%$ or less, leachate concentrations of elements of environmental and regulatory concem remained very low. Exceptions included Se mobilization with PFBC and increased concer LIMB. Dry FGD application is likely to be limited by high salt containing by-products such as the PFBC material, and by formation with $\mathrm{CaO}$ - and $\mathrm{Ca}(\mathrm{OH}) 2$ containing amendment rates are held at levels bew the LIMB material. If appears to be little are held at levels below those which would cause these effects, there LITERATURE CITED

1. Korcak, R.F. 1980. Fluidized bed material as a lime substitute and calcium source for apple seedlings. J. Environ. Qual. 9:147-151.

2. Fowier, R.K., J.M. Bigham, S.. Traina, U.I. Soto, R.C. Stehouwer, and E.L. McCoy. 1992. Properties of clean coal technology by-products. p. 361. In Agronomy abstracts. ASA,
Madison, WI.

3. Sutton, P., and W.A. Dick. 1987. Reclamation of acidic mined lands in humid areas. Adv. in Agron. 41:377-405.

4. Bohn, H.L., B.L. MCNeal, and G.A. O'Connor. 1985, Soil Chemistry, $2^{\text {nd }}$ Edition. John Wiley and Sons, New York.

5. Environmental Protection Agency. 1991. Method 1311: Toxicity characteristic leaching procedure (TCLP). p. 66-81. In Code of Federal Regulations, 40 CFR Ch. I (7-1-91 Edition)App. II.

6. Chaney, R.L., R.J.F. Bruins, D.E. Baker, R.F.Korcak, J.E. Smith, Jr., and D.W. Cole. 1987. Transfer of sludge-applied trace elements to the food-chain. p. 67-99. In Al Page, T.J. Logan, and J.A. Ryan (eds.) Land application of sludge: Food chain implications. Lewis Publishers Inc., Chelsea, MI.

7. Woodbury, P.B. 1992. Trace elements in municipal solid waste composts: A review of potential detrimental effects on plants, soil biota, and water quality. Biomass and Bioenergy 3:239-259.

\section{AKNOWREDGMENTS}

This research was condected as part of the "Land Application Uses for Dry FGD By-Products" project which is a cooperative project of the Ohio Agricultural Research and Development Center, The Ohio State University, The U.S. Geological Survey, and the Dravo Lime Company. Funding support for this project was obtained from the Ohio Coal Development Office (Columbus, OH) Grant No. CDO/D-89-35, the U.S. Department of Energy (Morgantown Energy Technology Center, Morgantown, WV Award No. DE-FC21-91 MC28060, Dravo Lime Company (Pittsburgh, PA) Grant no. RF768342. Electric Power Research Intitute (Palo Lime CA) Grant No. RP2796-02, American Electric Power Company (Columbus, OH) Grant No. 8276, Ohio Edison Company (Akron $\mathrm{OH}$ ) and Wooster, $\mathrm{OH}$ ). 
Table 1. Characterization of LIMB, PFBC, and spoil.

\begin{tabular}{|c|c|c|c|}
\hline Parameter & LIMB & PFBC & Spoil \\
\hline $\begin{array}{l}\text { Particle size (\%) } \\
\text { Sand }(0.05-2 \mathrm{~mm}) \\
\text { Sitt }(2-50 \mu \mathrm{m}) \\
\text { Clay }(<2 \mu \mathrm{m}) \\
\end{array}$ & $\begin{array}{r}0 \\
90 \\
10 \\
\end{array}$ & $\begin{array}{r}25.5 \\
74.1 \\
0.4 \\
\end{array}$ & $\begin{array}{l}14.4 \\
54.9 \\
30.7 \\
\end{array}$ \\
\hline $\begin{array}{l}\text { Mineralogy (\%) } \\
\text { Anhydrite }(\mathrm{CaSO}) \\
\text { Calcite }(\mathrm{CaCO}) \\
\text { Dolomite }\left(\mathrm{CaMg}\left(\mathrm{CO}_{3}\right)_{2}\right) \\
\text { Lime }(\mathrm{CaO}) \\
\text { Portlandite }\left(\mathrm{Ca}(\mathrm{OH})_{2}\right) \\
\text { Periclase }(\mathrm{MgO}) \\
\text { Fly ash }\end{array}$ & $\begin{array}{r}25 \\
15 \\
-21 \\
5 \\
- \\
30\end{array}$ & $\begin{array}{r}22 \\
11 \\
23 \\
- \\
\overline{13} \\
32\end{array}$ & $\begin{array}{l}\text { (Shale } \\
\text { fragments, } \\
\text { kaolinite } \\
\text { and illite } \\
\text { clays) }\end{array}$ \\
\hline $\mathrm{CaCO}_{3}$, oquiv. (\%) & 59.4 & 60.3 & 0 \\
\hline $\mathrm{pH}(1: 1$, water $)$ & 12.5 & 10.5 & 5.8 \\
\hline 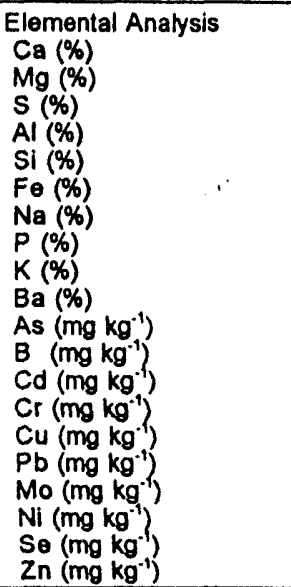 & $\begin{array}{r}35.96 \\
0.60 \\
5.77 \\
3.52 \\
6.58 \\
5.56 \\
0.33 \\
0.02 \\
0.91 \\
0.03 \\
55.1 \\
233.1 \\
1.0 \\
28.0 \\
21.0 \\
16.0 \\
5.9 \\
31.1 \\
8.1 \\
86.0\end{array}$ & $\begin{array}{r}17.53 \\
10.64 \\
5.21 \\
3.93 \\
7.24 \\
5.17 \\
1.03 \\
0.02 \\
0.50 \\
0.02 \\
1.9 \\
171.2 \\
1.9 \\
36.9 \\
52.5 \\
16.0 \\
6.6 \\
52.1 \\
5.6 \\
74.0\end{array}$ & $\begin{array}{c}<0.01 \\
0.18 \\
1.06 \\
9.2 \\
23.5 \\
1.3 \\
\overline{0} \\
0.04 \\
2.3 \\
0.04 \\
13.7 \\
\overline{0} .8 \\
79.8 \\
79.0 \\
30.5 \\
<0.9 \\
65.1 \\
4.3 \\
<0.3\end{array}$ \\
\hline
\end{tabular}

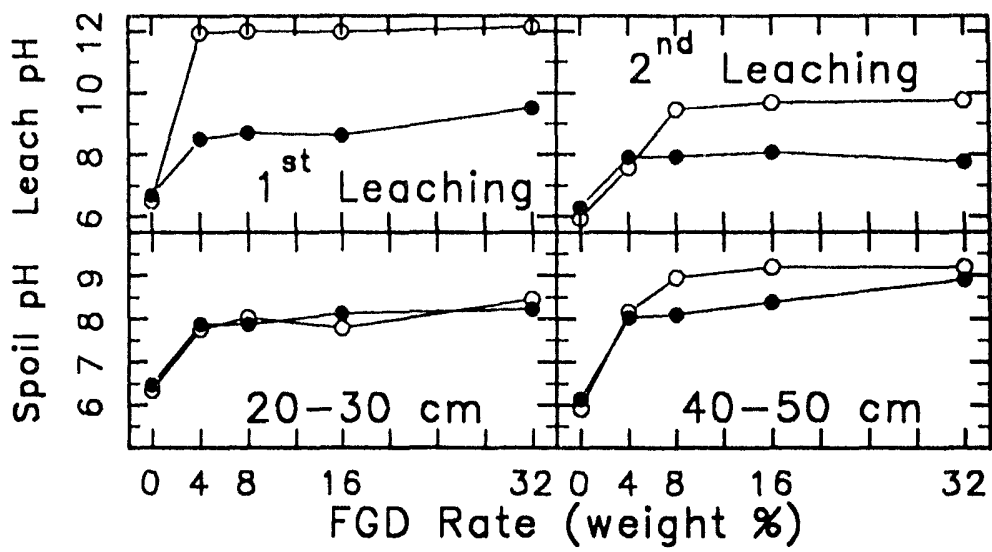

Fig. 1. First and second leachate $\mathrm{pH}$, and spoil $\mathrm{pH}$ at two column depths, of spoil columns amended with LIMB (O) and PFBC(O) by-products.

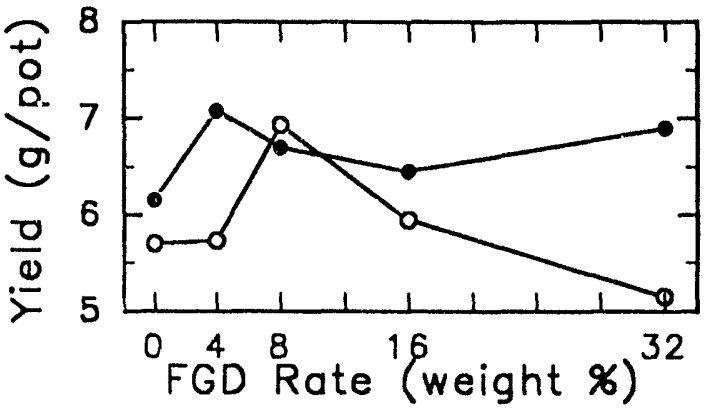

Fig. 2. Fescue yield from the sixth harvest of topsoll spoil columns amended with LIMB $(0)$ and PFBC(O) by-products.

Table 2. Chemistry of leachates from columns of active mine topsoil and spoil amended with FGD by-products.

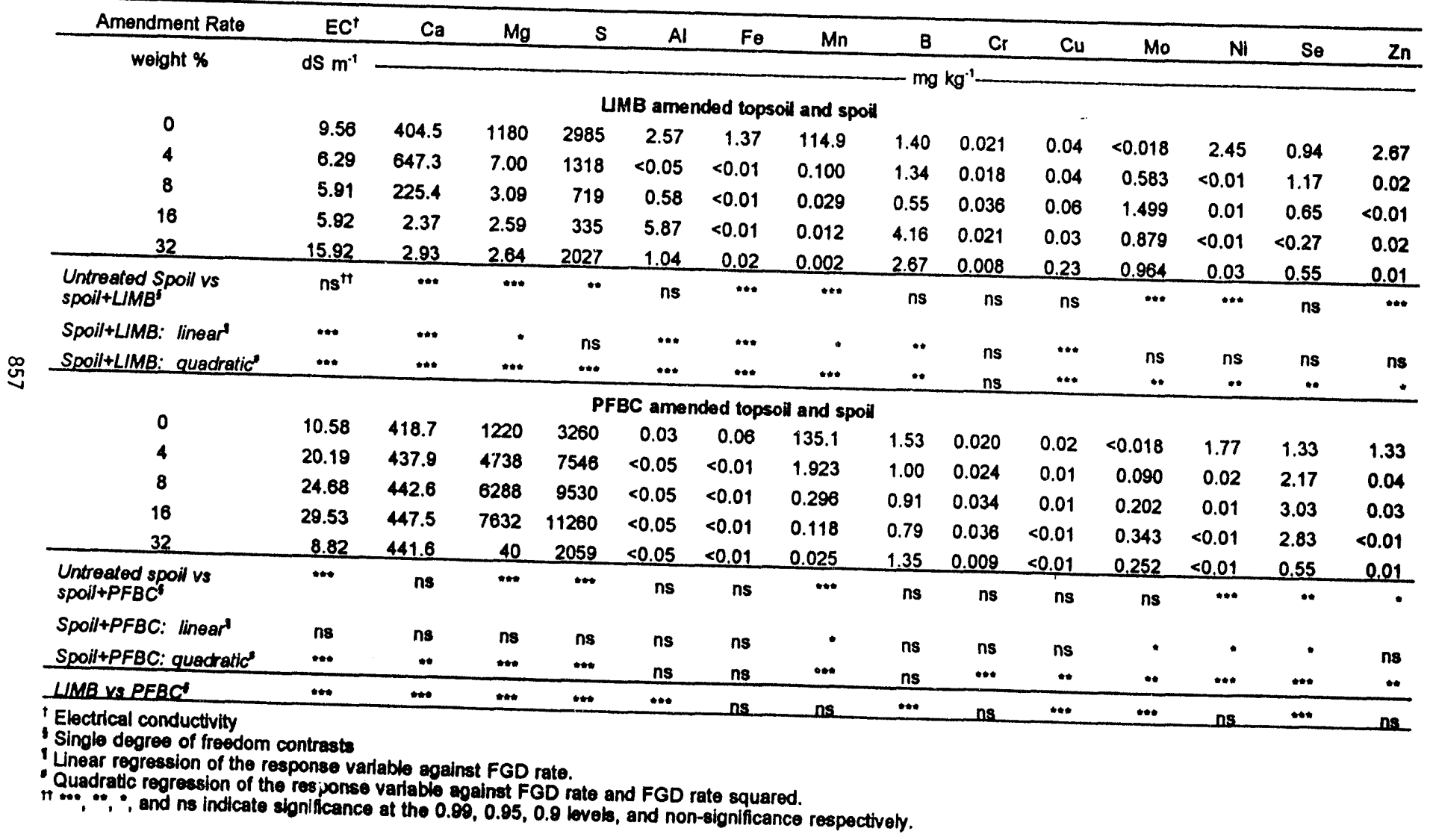




\section{TABLE 1}

Land Applications Uses of Dry FGD By-Products

OSU ONLY Sept., 1990 Original Budget and Subsequent Revisions

$\begin{array}{llrrr} & \begin{array}{l}\text { Original } \\ \text { Budget } \\ \text { Sept.'90 }\end{array} & \begin{array}{c}\text { Revised } \\ \text { Budget } \\ \text { June,1991 }\end{array} & \begin{array}{c}\text { Revised } \\ \text { Budget } \\ \text { March,1992 }\end{array} & \begin{array}{c}\text { Revised } \\ \text { Budget } \\ \text { Sept.1993 }\end{array} \\ \text { PHASE 1 } & \$ 586,160 & \$ 712,521 & \$ 701,849 & \$ 701,849 \\ \text { PHASE 2 } & \$ 1,905,398 & \$ 1,730,832 & \$ 1,737,075 & \$ 1,739,480 \\ \text { PHASE 3 } & \$ 1,677,641 & \$ 1,725,844 & \$ 1,730,274 & \$ 1,727,870 \\ \text { TOTAL } & \$ 4,169,199 & \$ 4,169,199 & \$ 4,169,199 & \$ 4,169,199\end{array}$


From A-1

\section{Meeting}

Dover will do everything within its means to prolect its sourse of drinking waler," Homrighausen said. "This is not mercly 'not in my back'ard' argument, but one

Paulus said his study of the area revealed 50 to 60 privale water supplics locisted w'lthin mile of the area to be reclaimed.

"The rescarch and work in this (study of reclamation matcrials and sites) needs to be done." Paulus said, "but we also feel that we need to have it done in an arca where the public healih is not threatence. There are 100 many unknow'n ractors in this area for a project of this type."

Steve Wermuth, county health commissioner, and Franklin Tow'nship Trustee Max Bonifant said they have received many questions from ares residents about the project, but have had minimal or no contact with state omcials about it, Wermulh said a copy of the application has never been sent to the health depart. ment.

According to the $\$ 380,000$ plan developed by Ohio Slale Univer. sity and ODNR Onicials, sewer sludge from roledo - the solid material renoved during treat. ment of municipal wastewater $\rightarrow$ would be applice on two one. acre plots as part of a sludy of materials used to reclalm mine sites. An elght-acre plot using a Commercially produced sludge materlal also is part of the plan. OF Other materials to be lested at Obe sile are lime and nue $z$ as des. plnurizalion byproduct, the waste product of coal burned by utili. Hes. Application would not begin sefore the spring of 1994, said Wirk Smith, an oDNR environ. mental specialist.

SOEPA ofmcials said testing at indge application sltes in Ohio ming the past 10 ycars has re. * Led no major problems posed me environment and health of Tounding residenls. The Blue Fk Coal mine sile, which has ured erosion ratcs much * than normal for several Fould not exceed current on all identined harmnal

tan injured fairgrounds Hifyenrold employec of substances.

However, several arca omiclals and residents said that dcbale continues among experts about the existence of sale levels for substances such as lead and diox. ins.

"We're here to make sure the current regulations are being mal, not to write ncw ones," said Mark Stump, OEPA environinen. (a) supervisor. "We're not going lo lesve the sludre out there and leave it unlouched. There are several more projects to be done on it, such as growing grass and mulching."

Marco Kaltofen president of Boston Chemical Data Co. and a witness contacted by residents opposing the project, said he considers the proposal as a landnil.

"Thls is an experiment," said Kaltolen, who had to lcave midway through the hearing to re. lurn to Boston. "This is a chance to find something oul. Something is unknown, so there are guines pigs involved."

Other arguments raised during the hearing included the rates of sludge being applled liability in case something would go wrong at the sile and whether Terry Logan, an OSU agronomy professor who helped to develop the plan, had created a connict of Intercst by serving as a consultant for National N. Viro Tech of To. ledo, the company manufacturing the sludge-luke material

The hearing, which strelched beyond three hours, is part of the application process for a project permlt. Tcstimony from the hearing will be considered in the final determination for granting and or altering an application. State orlicials said they could not detcrmine when anal decision on the project application would be made by OEPA.

ODNR omclals said work re. cently begun on the site involves reclamation with the topsoil only and is not considered part of the project arca. The land is owned by Don Domer of Dover.

Kaltofen, who said he has vis. itcd many sludge applleation sites throughout the country, said Boston pays $\$ 400$ pcr ton to dispose of its sludce.

"The lucky people of Dover ... you're actually going to get this sturf for roe," he said. 


\section{N-VIRO SOIL'S PART IN THE RECLAMATION OF THE FLEMING ABANDONED MINE SITE}

The N-Viro Soil (NVS) or Advanced Alkaline Stabilizad Sludge with Accelerated Drying (AASSAD) process is a US and Ohio EPA approved Process to Further Reduce Pathogens (PFRP) and produces an Exccptional Quality Sludge (EQS) product. Dewatercd municipal biosolids (sludge cake) are mixcd with other alkaline by-products such as lime kiln dusi (LKD), cement kiln dust (CKD) or fluidized bed boiler ash (FBA). The resultant mix causcs the material to heat up to betwecn $52^{\circ} \mathrm{C} 1062^{\circ} \mathrm{C}$ (pastcurization temperalurcs, and the $\mathrm{pH}$ is increased to 12. The mixturc is storcd to maintain these tcmpcraturcs for al least 12 hrs. Afler this, the heal trealcd matcrial is dricd (whilc the pH remains above 12 for at least throe days) through intermittent lurning of windrows or other drying proxesses, until the sollids levels reach and maintain a minimum of $50 \%$. The mechanisms of pastcurization and the increasc in pH causcs all pathogens to be destroyed while maintuining the normal soil microbes. It also converts any heavy metals present into insoluble minerals .

N-VIRO PROCESS COMPARED TO OTHERS: Unlike traditional high heut lime pastcurization/ stcrilization, the N-Viro process docs not have to use large dosages of quicklime or maintuin the matcrial at $\mathrm{pH} 12$ until land applicd. The pH of NVS will decrease through the normal weathering process cven in storage with no fear of pathogen regrow th. This is due to the natural soil microbes present in the NVS and the dry, soil-like consistency.

The NVS made in Toledo, Galion, and Circleville, Ohio and throughout the Unitcd Statcs, England and A ustralia all adhere to the company's strong Quality Assurance/Quality Control Program. The N-Viro process and product also has to mect the most stingent State and Fedcral regulations for the marketing and distribution of an EQS product.

NVS IN THE MARKETPLACE: In Ohio, the largest market for NVS is presently as an agricultural lime substilutc. Since 1990, we have sold over 65,000 tons to farmers and another 15,000 tons to other markcts such as topsoil manufacturing and landfill cover. Farmcrs can buy NVS for a price equal to or less than lime and receive the added bencfit of the NPK, ortanic malker, micronutrienis and soil microbes prescnl.

NVS AND MINEL AND RECLAMATION: In 1988, a projccl was begun in Hopkins Co., Kenlucky in conjunction with the Kentucky Depurtment sf Nalural Resources that uscd a NVS producl out of Bowling Grecn KY to reclaim a site that had been surface mined in the 1950's. The $\mathrm{pH}$ of the arca was 2.5 and consisted of sandy soil and roxks. After NVS was applied, the arca H'as sceded with a stundard reclamation mix. No additional fertilizer was applicd to the sitc. After three kecks grasses began to grow and by the following spring the grass was thick and tall with no "weak" spots. Arcas which did not reccive NVS were stressed by the low pH and showcd litle or no vegetatic grous th. The site has been revisited screral timcs since the test and the grow th remains strong. Bascd on the results of this project, the Kenlucky Division of Abandoned Mine Lands has placed $\mathrm{N}$ V Viro Soil on its list of approved reclamalion matcrials. This allows contractors to use NVS on reclamation projects overseen by A banduncd Lands. The contractors like the NVS because it costs $50-60 \%$ less than conventional reclamation matcrials while providing $75 \%$ better rcsults.

THE FIEMINO AB ANDONED MINELAND PROIECT: When NVS was propused for usc in mincland reclamation for the first lime in Ohio, we wanked to begin with a rescarch project. We know it is importunt for Ohioans to sce and understand how this matcrial will work in their stutc. At the Fleming minc site NVS will be applied to two, one acre plots at a rate of 250 tons per acre. This is so the lime value of the NVS plsts will match the lime value of the plots annended with regular agricultural lime. There is also an eight acre area surrounding the rescarch plots being called a buffer $z$ one that will receive NVS al a ralc of 100 tons per acre. Thereforc, a tobal of ten acres will hate NVS applicd to them. 

GREAT LAKES

\section{$\mathrm{N}-\mathrm{VIR} \odot$}

\section{N-UIRO SOIL'M \\ ORGANIC RG LIME}

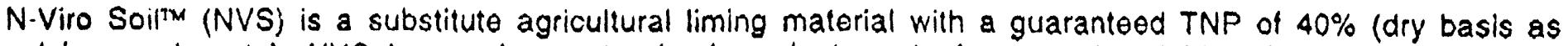
calclum carbonate). NVS is a sale, pasteurized product made from municipal biosolids and alkaline byproducts such as lime or cement kiln dust and fluidized bed boiler ashes. NVS is also a source of organic matter, macro- and micro-nutrients and natural soll microbes. NVS moets all state and federal guldelines for sludge derived products with regard to pathogen destruction, heavy metal concentrations and odors and vector attraction

\section{INSTRUCTIONS FORUSE}

NVS may be used where soil tosts indicate a need for an agricultural liming agent. The rate of application is dependent on the recommended tons of lime per acre needed.

Example: If the NVS TNP is $50 \%$ and the soil test indicates a need for 4 tons/acre of ag lime, use 8 tons/acre of NVS

\section{LIMING VALUE}

The particle size of NVS is much finer than many agricultural limestones, thus reacts to adjust $\mathrm{pH}$ of the soil quickly, within one month. The high pH of NVS is due to the presence of small amounts of calclum hydroxide. NVS contains a large amount of $\mathrm{CaCO}_{3}$. When exposed to air, it carbonates within minutes and the $\mathrm{pH}$ will be buffered to about 8.0.

Table 1

\begin{tabular}{|l|r|}
\hline NUIFIEN & Ibs/OT \\
\hline Nitrogen & 14 \\
\hline P205 & 27 \\
\hline K20 & 10 \\
\hline Calcium & 388 \\
\hline Magnesium & 161 \\
\hline Suivr & 52 \\
\hline Zinc & 0.45 \\
\hline Copper & 0.13 \\
\hline Manganese & 0.60 \\
\hline
\end{tabular}

\section{NVSMETALSANALYSIS}

The heavy metal content of NVS is tested continuosly. lietals levels are guaranteed to lall below all state and federal rules regulating their concentration in biosolds derived products. Table 2 compares the concentration of metals in NVS with that of inorganic, synthetic tertilizers and the EPA limits for land application.

\section{SPREADINGNVS}

NVS can be spread with lime $9 / 0$ r manure spreaders. Fill hopper approximately $3 / 4$ of the way to prevent bridging of the material.

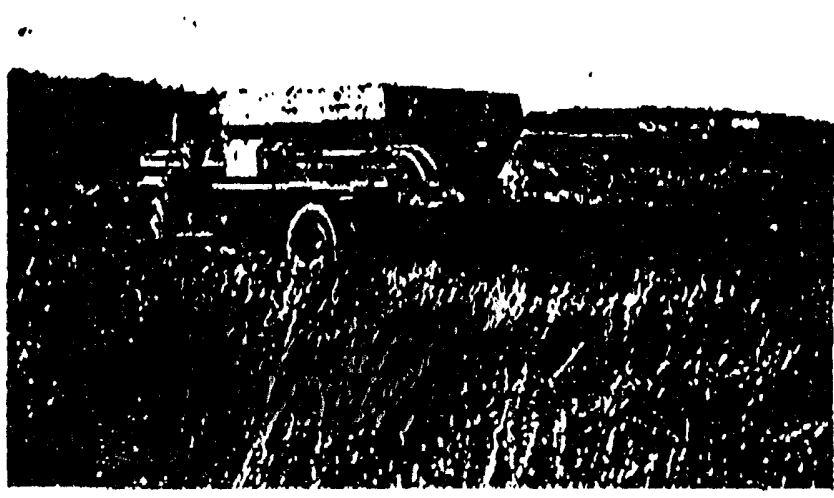

DLANT NUTRIENTS

The nitrogen in NVS is almost entirely organic, therefore it acts like a slow release fertilizer. Research Indicates that approximately $20 \%$ of the nitrogen is available during the first year with continual mineralization yielding another $5 \%$ per year. $50 \%$ of the phosphorus and $100 \%$ of the potash $(K)$ will be available. Table 1 shows an average of the lbs/acre of PK and micronutrients you mighi find in NVS. These values are based on 1993 analysis and are not guaranteed.

Table 2

\begin{tabular}{|l|r|r|r|}
\hline $\begin{array}{c}\text { HEAVY } \\
\text { METALS }\end{array}$ & $\begin{array}{r}\text { 1993 AVG NVS } \\
\text { CONC.(mgikg) }\end{array}$ & $\begin{array}{r}\text { EPAEQS } \\
\text { LMITS }\end{array}$ & $\begin{array}{r}\text { AVG SYN } \\
\text { FERT CONC }\end{array}$ \\
\hline Arsenlc & 15.8 & 41 & 13 \\
\hline Cadlum & 1.9 & 39 & 12.4 \\
\hline Chromlum & 72.4 & 1200 & 129 \\
\hline Copper & 95.5 & 1600 & 55 \\
\hline Lead & 65.4 & 300 & 36 \\
\hline Mercury & 0.4 & 17 & 0.1 \\
\hline Molybdenum & 10.3 & 18 & \\
\hline Nickel & 120.2 & 420 & 81 \\
\hline Selenium & 4.6 & 36 & \\
\hline Zinc & 355.9 & 2800 & 230 \\
\hline
\end{tabular}




\section{N-VIRO IN THE NEWS}

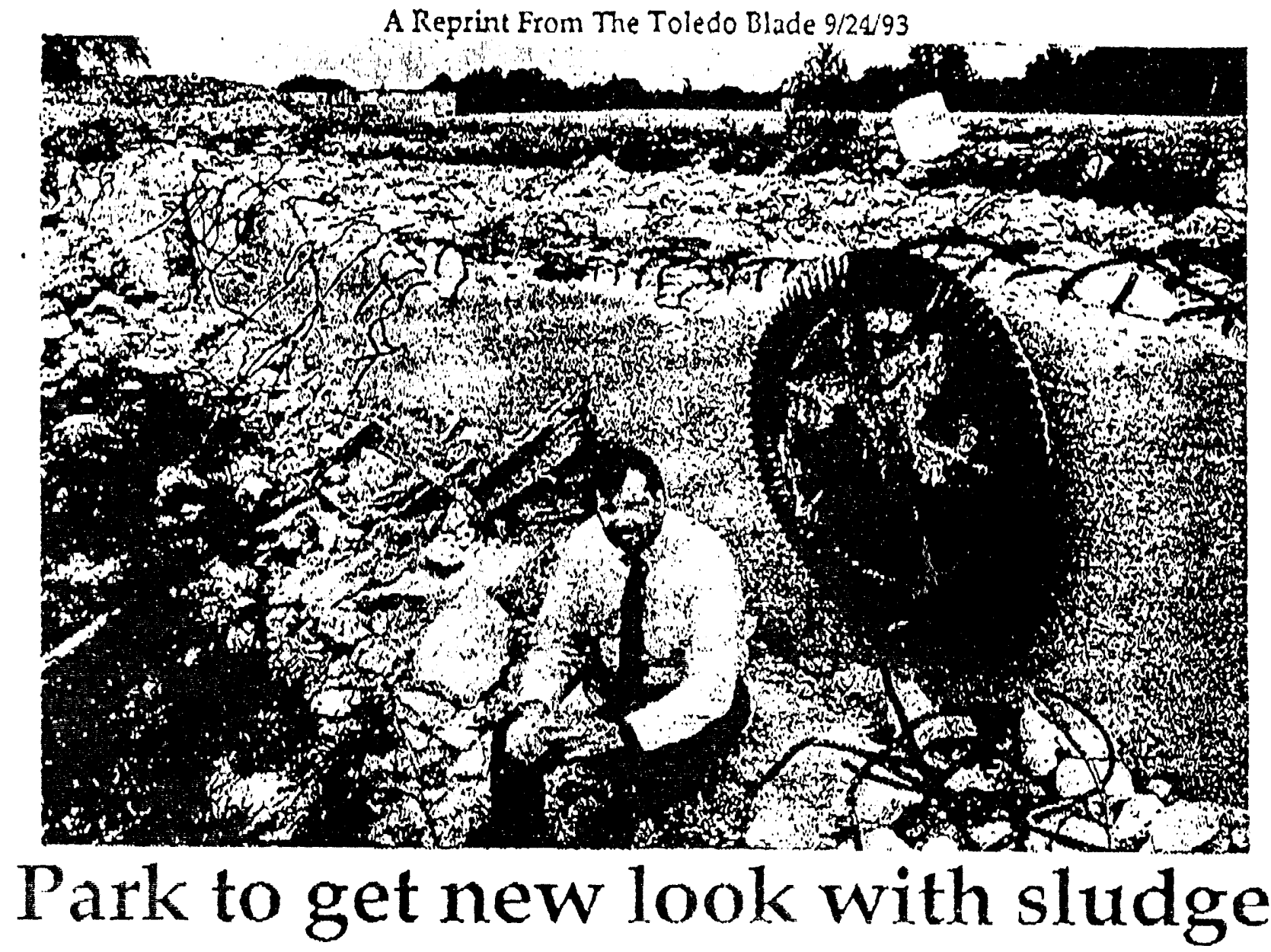

A Suth Tolsto gark might end up cume a ine oft geener, thanks to a sol adiste that combines

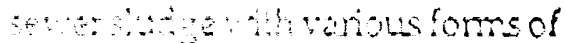
dustantash

Fot horstarthavefertilized not datorytading the sewage browour on it sludae is a moist matal arred at the city's senazo yom when the waste stom somet atany bouds Ate:

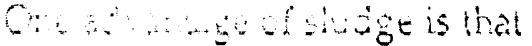

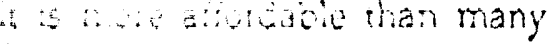
ariaces

sond a ridy to use then setion of the

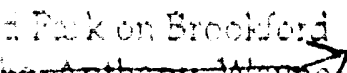
(ait D. zaroy while adoing nution to the suti, Water Com ssantwh Var Cottsid. The lat he Bun undergoing a

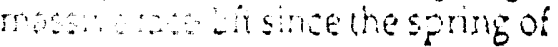

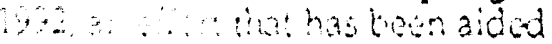
wherem the Ohio
The section under resus =urion was the site of a wastewater treatment plarit that had hage reservirs dating back to 390 .

The plant wos demolishod months ago. The crushed crencete from the plant was left there and covered by about thee ?ert of $\mathrm{AR}$, Mr. l'an Colt said.

The dirt was coverad by a fourinch ayyer of Envirosoi, a probuc developed by Great Likes N-Viro. a subsidiary of N-Viro anegy Systems of Toloto.

Envirosol consists of sucend alkoline by-protucts such as dus: from line kilns, cument klrs, and ash, Gindy Dali, poduct momger for Creat Lakes. Viro, said.

Ey using the siudge produrt, the city can save on fertiizer ard dit costs while supporting a local company, Mir Van Cott said.

The city has spent about $\$ 260,000$ on renovationsolar, indudingabout $\$ 45,000$ for 3,000 rubic yards of

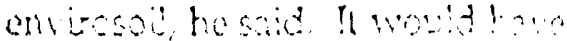

cosi about another $\$ 35,000$ if the final layers consisted of topsoil. he said.

The sludge-and-dust product has been inixed with existing dirt and clay at the site, and officials expctit to find out soon how well the stuff works.

The grass was flanted yecterday, Ms. Drill said.

City officials have said the rerovation is not expected to be corpleted for another two to aye years. The sty stii needs to obtain funds so: landscaping, and to install new ́acilizos, Mr. Van Cott sad. Thu are working off a naster Flun dxaroup in Augut, 1991.

Envirosid is likely to remain more popular on fans.

$N$-Viro has sold 65,000 tons of Envirosoil :o area farmess since $1900, \mathrm{~A}$ s. Erill said. About 15,000 tons have been sold for other puposes, such as landfill cover, shesaid. 

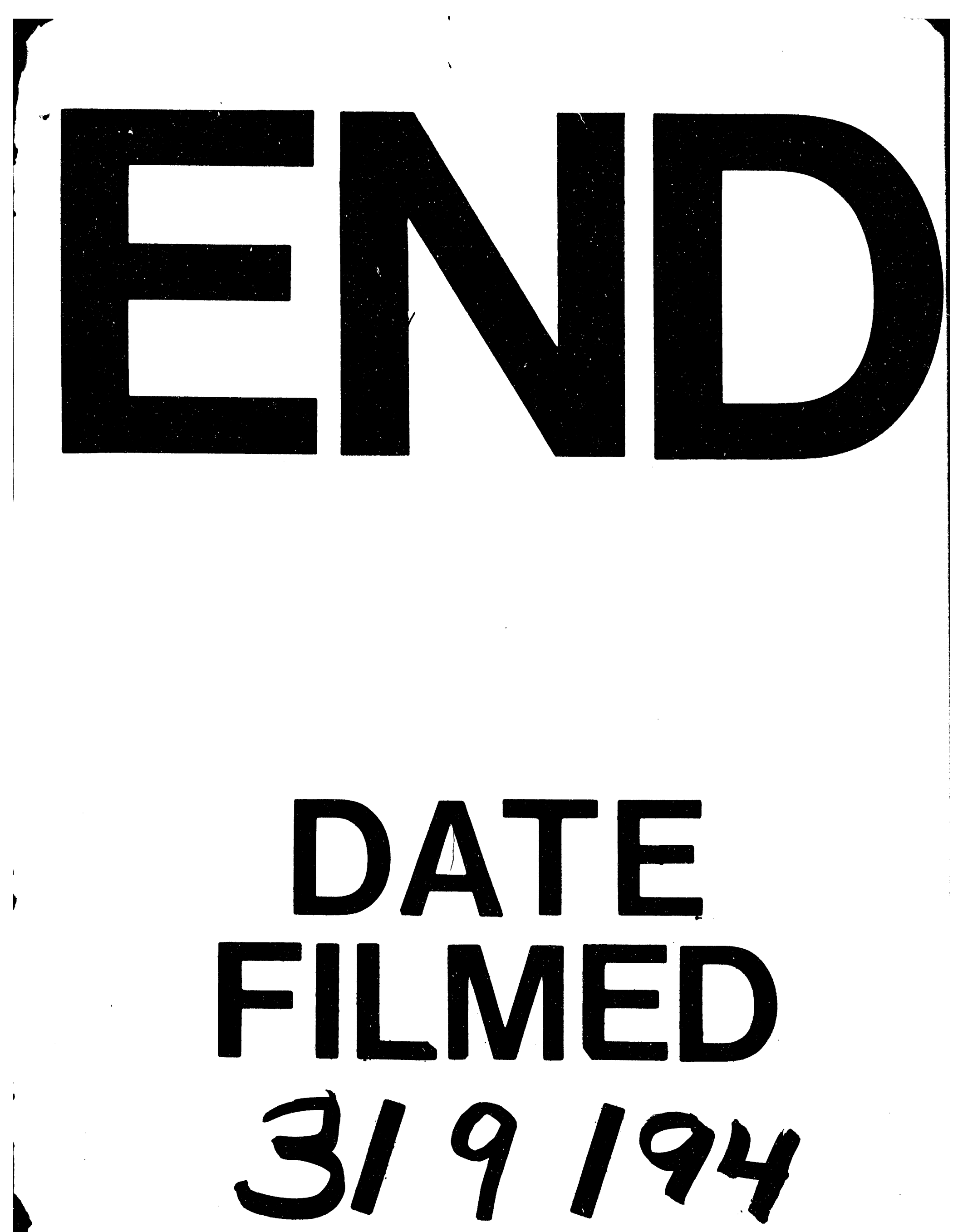
